\title{
Motor Intervention and Assessment Instruments in Autism Spectrum Disorders
}

\author{
Carla Lourenço1, Dulce Esteves² \\ ${ }^{1}$ Department of Sport Science, University of Beira Interior, Covilhã, Portugal \\ ${ }^{2}$ Sports Sciences, Health Sciences and Human Development, CIDESD, Vila Real, Portugal \\ Email: ccvl@ubi.pt
}

How to cite this paper: Lourenço, C., \& Esteves, D. (2019). Motor Intervention and Assessment Instruments in Autism Spectrum Disorders. Creative Education, 10, 1929-1936. https://doi.org/10.4236/ce.2019.108139

Received: July 11, 2019

Accepted: August 19, 2019

Published: August 22, 2019

Copyright $\odot 2019$ by author(s) and Scientific Research Publishing Inc. This work is licensed under the Creative Commons Attribution International License (CC BY 4.0).

http://creativecommons.org/licenses/by/4.0/

\begin{abstract}
The practice of physical activity in people with disabilities provides important health benefits (Wind, Schwend, \& Larson, 2004; Chanias, Reid, \& Hoover, 1998), particularly in individuals with autism spectrum disorder (ASD). Several motor interventions have been suggested as beneficial for this population. Considering this variety, it is important to synthesize the different existing programs, the population in which they are applied. This research aims to review the motor interventions used in children with ASD, as well as the evaluation methods used, so that it becomes clear what the options are for motor work with this population. All the studies presented showed improvements in participants. A literature search was conducted in Web of Science, SCOPUS and Google Scholar 2013, to include research studies that evaluate motor intervention in children with ASD. Fifteen studies meet inclusion criteria. Results show that motor intervention programs that have been carried out are quite diverse, from dance, trampoline training, balance training or fundamental motor skills, for example, to evaluate motor skills which used different test batteries, one of the most common is the motor proficiency test of Bruininks-Oseretsky. On the other hand, other methods were used to evaluate the social interaction like Gilliam Autism Rating Scale or Autism Rating Scale. We conclude that to improve the motor fitness of children with ASD different strategies can be followed. As the revised programs use different evaluation tools, it is difficult to compare the results obtained with each other. A motor intervention that comprises different types of exercises and materials, using ludic exercises may be a potentially more effective strategy.
\end{abstract}

\section{Keywords}

Autism Spectrum Disorder, Motor Intervention Program, Assessment Instruments 


\section{Introduction}

Autism spectrum disorder (ASD) is a neurological disorder that is characterized by impairments in communication and social skills, and is associated with repetitive behavior and stereotypical movements (Dillon, Adams, Goudy, Bittner, \& McNamara, 2017). Many children with ASD motor and sensory difficulties are observed (Baranek, 2002). Several studies have also reported changes in the motor development profile of these children contributing to a lower physical fitness (Loh et al., 2007; Ozonoff, Young, Goldring, Hess, Herrera, \& Steele, 2008; Pan et al., 2009; Fournier, Hass, Naik, Lodha, \& Cauraugh, 2010). The strategies for the treatment of ASD are focused mainly on cognitive stimulation, social and language development and the elimination of stereotyped movements (Koenig et al., 2010 in Sowa \& Meulenbroek, 2012).

Research suggests that exercise is beneficial for improving children with ASD motor coordination, balance, and flexibility. It also reduces their stereotypical behavior and has positive effects on socialization, and communication (Bremer, Crozier, \& Lloyd, 2016; Lang, Liu, \& Ledbetter-Cho, 2018; Sam, Chow, \& Tong, 2015).

Therefore, motor intervention programs have been increasingly used for the development of children with ASD, both at the motor level and at the social level. Motor deficits are a hallmark of autism spectrum disorders and the treatment of this pathology should consider interventions to improve these deficits, including motor performance involved with motor coordination (gait, balance, arm functions and movement planning) (Fournier, Hass, Naik, Lodha, \& Cauraugh, 2010) or even associate activity or physical exercise with the development of communication and socialization.

In order to evaluate the effects of motor intervention programs, assessment instruments (test batteries, questionnaires) are commonly used. There are many instruments of motor evaluation, however, neither is perfect nor encompasses all aspects of development (Neto, 2007).

Considering the variety of motor programs used in children with ASD presented in literature, it is important, for those intending to make a practical motor intervention, to synthesize the different existing programs, the population in which they are applied and the improvements that each.

In this sense, the present work seeks to review the motor interventions used in children with ASD, as well as the evaluation methods used, so that it becomes clear what the options are for motor work with this population.

\section{Methods}

\section{Research Procedures}

This research was carried using a narrative revision comprehending three databases: Web of Science, SCOPUS and Google Scholar. The key words used were autism spectrum disorders, motor program. The research was carried out based on articles published since 2013 until now. The main reason for this methodo- 
logical decision was the existence of two systematic reviews on the subject, date 2012.

According to the objective of the work, we considered as inclusion criteria: 1) the participants-children or adolescents with the diagnosis of ASD; 2) the motor intervention programs used based on physical activity. As exclusion criteria we considered all interventions that only focused fine motor control, or interventions that were not described in the research (Figure 1).

Of the 15 studies presented, all participants had diagnosed ASD and were children or youth/adolescents. The ages range from 4 to 16 years old. All studies performed between 2013 and 2018, which resulted from motor intervention programs performed in children or young people with ASD.

\section{Results and Discussion}

Table 1 synthetized the essential information of articles retrieved. For each study the first author and year of publication are presented, the type of intervention performed and duration, the total number and age of the participants, evaluation instruments used to evaluate the variables under study and the main results.

The results of the motor programs were presented between 2013 and 2018, having been studied with different activities in children with ASD. These activities range from: dance, trampolines, assisted cycling, equine or more specific activities with the aid of training or core development.

The impact of different intervention programs on the social and motor dimensions was studied.

As for the evaluation instruments, it was verified that a practical evaluation was carried out through different instruments: Korperkoordinations test für Kinder (KTK) (Kiphard \& Schilling, 1974), Movement Evaluation Battery for Children-2 (MABC-2), Bruininkse Oseretsky Motor Proficiency Test

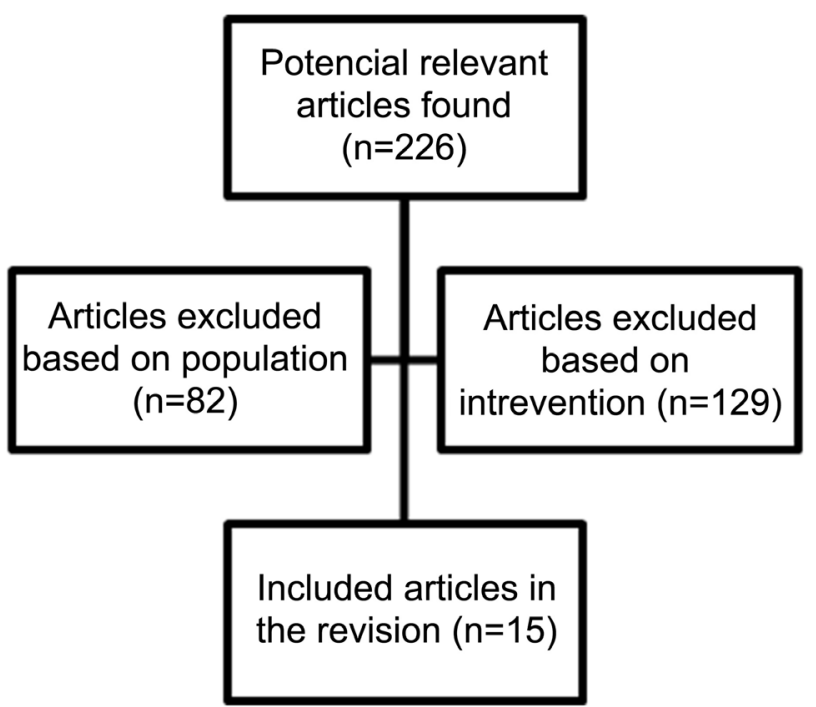

Figure 1. Fluxogram of article selection. 
Table 1. Motor intervention programs performed with children with ASD.

\begin{tabular}{|c|c|c|c|c|}
\hline Author & Motor program and duration & Participants & Assessment instruments & Results \\
\hline $\begin{array}{l}\text { Arzoglou et al. } \\
\text { (2013) }\end{array}$ & $\begin{array}{l}\text { Greek traditional dance training } \\
\text { program; } \\
8 \text { weeks; } 3 \text { times per week; } \\
\text { duration } 35 \text { - } 45 \mathrm{~m} \text {. }\end{array}$ & $\begin{array}{l}10 \text { individuals with autism; } \\
\text { Average age } 16 \text { years old. }\end{array}$ & $\begin{array}{l}\text { Korperkoordinations test für } \\
\text { Kinder (KTK) (Kiphard \& } \\
\text { Schilling, 1974). }\end{array}$ & $\begin{array}{l}\text { Improve their } \\
\text { neuromuscular } \\
\text { coordination. }\end{array}$ \\
\hline Borgi et al. (2016) & $\begin{array}{l}\text { Equine assisted therapy; } \\
1 \text { a week; } 6 \text { months; } \\
60 \text { - } 70 \text { min. }\end{array}$ & $\begin{array}{l}28 \text { children with ASD; } \\
6 \text { - } 12 \text { years. }\end{array}$ & $\begin{array}{l}\text { Vineland Adaptive Behavior } \\
\text { Scale (VABS, Sparrow et al. } \\
\text { 1984); Tower of London (TOL, } \\
\text { Shallice, 1982). }\end{array}$ & $\begin{array}{l}\text { Improvement in social } \\
\text { functioning; Milder effect on } \\
\text { motor abilities. }\end{array}$ \\
\hline $\begin{array}{l}\text { Bremer et al. } \\
\quad(2014)\end{array}$ & $\begin{array}{l}\text { Fundamental motor skill; } \\
1 \text { h/week for } 12 \text { weeks vs. } 2 \\
\text { h/week for } 6 \text { weeks. }\end{array}$ & $\begin{array}{l}9 \text { children with ASD; } \\
4 \text { years old. }\end{array}$ & $\begin{array}{l}\text { Movement Assessment Battery } \\
\text { for Children-2 (MABC-2); } \\
\text { Vineland Adaptive Behavior } \\
\text { Scales-2 (VABS-2) } \\
\text { The Social Skills Improvement } \\
\text { System (SSIS). }\end{array}$ & $\begin{array}{l}\text { Significant improvement of } \\
\text { children's skills in the } \\
\text { experimental group. }\end{array}$ \\
\hline $\begin{array}{l}\text { Cheldavi et al. } \\
\text { (2014) }\end{array}$ & $\begin{array}{l}\text { Balance training; } 45 \mathrm{~m} / \text { session; } \\
3 \text { session per week; } 18 \text { sessions. }\end{array}$ & $\begin{array}{l}20 \text { boys with high } \\
\text { functioning ASD; } \\
7 \text { - } 10 \text { years old. }\end{array}$ & $\begin{array}{l}\text { Bertec force plate (type strain } \\
\text { gage, } 40-60)\end{array}$ & $\begin{array}{l}\text { Improved the postural } \\
\text { control. }\end{array}$ \\
\hline $\begin{array}{c}\text { Dickinson \& Place } \\
\text { (2014) }\end{array}$ & $\begin{array}{l}\text { Nintendo Wii and the software } \\
\text { package "Mario and Sonics at the } \\
\text { Olympics"; } 15 \mathrm{~m} \text { day } / 3 \text { week. }\end{array}$ & $\begin{array}{l}50 \text { children with ASD; } \\
5 \text { - } 15 \text { years. }\end{array}$ & Eurofit. & $\begin{array}{l}\text { Statistically significant } \\
\text { improvement on all tests. }\end{array}$ \\
\hline $\begin{array}{l}\text { Golsefidi et al. } \\
\text { (2013) }\end{array}$ & $\begin{array}{l}\text { Core stabilization training; } \\
8 \text { weeks; } 3 \text { times/week. }\end{array}$ & $\begin{array}{l}20 \text { children with high } \\
\text { functioning autism. }\end{array}$ & $\begin{array}{l}\text { Stork test to assess static balance; } \\
\text { To evaluate the dynamic balance, } \\
\text { the beam was used, where the } \\
\text { child walked. }\end{array}$ & $\begin{array}{l}\text { The study showed that core } \\
\text { stabilization exercises can } \\
\text { improve static and dynamic } \\
\text { balance and can be done } \\
\text { along with other exercises. }\end{array}$ \\
\hline $\begin{array}{l}\text { Hilton et al. } \\
\quad(2014)\end{array}$ & $\begin{array}{l}\text { Exergaming, specifically the } \\
\text { Makoto arena training } \\
\text { intervention; } \\
30 \text { sessions; } 3 \text { per week. }\end{array}$ & $\begin{array}{l}7 \text { with ASD; } \\
6-13 \text { years. }\end{array}$ & $\begin{array}{l}\text { Behavior Rating Inventory of } \\
\text { Executive Function } \\
\text { (BRIEF); BOT-2. }\end{array}$ & $\begin{array}{l}\text { Improvement in the } \\
\text { executive function, working } \\
\text { memory, metacognition, } \\
\text { strength and agility. }\end{array}$ \\
\hline $\begin{array}{l}\text { Ketcheson et al. } \\
\qquad(2017)\end{array}$ & $\begin{array}{l}8 \text {-week } \\
\text { Motor skill instruction } 4 \mathrm{~h} / \text { day; } \\
5 \text { days/week. }\end{array}$ & $\begin{array}{l}20 \text { children with ASD; } \\
4 \text { - } 6 \text { years old. }\end{array}$ & $\begin{array}{l}\text { Test of Gross Motor } \\
\text { Development-2 Accelerometers; } \\
\text { Playground Observation of Peer } \\
\text { Engagement. }\end{array}$ & $\begin{array}{l}\text { Statistically significant } \\
\text { changes at the locomotor } \\
\text { level object control and gross } \\
\text { quotient. }\end{array}$ \\
\hline Kruger (2018) & $\begin{array}{l}\text { Dance } \\
14 \text { seminars; } 2 \text { per week; } \\
50 \text { m per section. }\end{array}$ & $\begin{array}{l}9 \text { children with ASD; } \\
5 \text { - } 10 \text { years old. }\end{array}$ & $\begin{array}{l}\text { Test of Gross Motor } \\
\text { Development" (TGMD-2); } \\
\text { Childhood Autism Rating Scale } \\
\text { (CARS). }\end{array}$ & Improved motor skills. \\
\hline $\begin{array}{l}\text { Lanning et al. } \\
\text { (2014) }\end{array}$ & $\begin{array}{l}\text { Equine assisted activities; } \\
12 \text { weeks; } \\
1 \text { hour per session; }\end{array}$ & $\begin{array}{l}25 \text { children with ASD } \\
4-15 \text { years. }\end{array}$ & $\begin{array}{l}\text { Pediatric Quality of Life } 4.0 \\
\text { Generic Core Scales (PedsQL); } \\
\text { Child Health Questionnaire } \\
\text { (CHQ). }\end{array}$ & $\begin{array}{l}\text { Improvements in physical, } \\
\text { emotional and social } \\
\text { functioning and in behavior. }\end{array}$ \\
\hline $\begin{array}{l}\text { Lourenço et al. } \\
\qquad(2015 \mathrm{a})\end{array}$ & $\begin{array}{l}\text { Trampoline training; } \\
1 \text { session/week; } \\
45 \text { minutes; } \\
20 \text { weeks. }\end{array}$ & $\begin{array}{l}17 \text { children with ASD; } \\
4 \text { - 10years old. }\end{array}$ & $\begin{array}{l}\text { Bruininks-Oseretsky ( } 2^{\mathrm{a}} \text { ed. } \\
\text { 2005), short form. }\end{array}$ & $\begin{array}{l}\text { Significant Improvements in } \\
\text { motor proficiency, bilateral } \\
\text { coordination, balance, speed } \\
\text { and agility and strength. }\end{array}$ \\
\hline $\begin{array}{l}\text { Lourenço et al. } \\
\qquad(2015 b)\end{array}$ & $\begin{array}{l}\text { Trampoline training; } \\
1 \text { session/week; } \\
45 \text { minutes; } \\
32 \text { weeks. }\end{array}$ & $\begin{array}{l}\text { 16children with ASD; } \\
4 \text { - } 11 \text { years. }\end{array}$ & $\begin{array}{l}\text { Bruininks-Oseretsky }\left(2^{\text {a }} \text { ed. }\right. \\
\text { 2005), short form. The strength } \\
\text { of the lower limbs was estimated } \\
\text { by a long jump with both feet } \\
\text { together (without run up). }\end{array}$ & $\begin{array}{l}\text { Significant way to the } \\
\text { improvement of both the } \\
\text { strength of the inferior limbs } \\
\text { and motor } \\
\text { proficiency. }\end{array}$ \\
\hline $\begin{array}{l}\text { Movahedi et al. } \\
\text { (2013) }\end{array}$ & $\begin{array}{l}\text { Kata techniques training; } \\
14 \text { weeks; } 4 \text { days/week. }\end{array}$ & $\begin{array}{l}30 \text { children with ASD; } \\
5 \text { - } 16 \text { years. }\end{array}$ & $\begin{array}{l}\text { Gilliam Autism Rating } \\
\text { Scale-Second Edition (GARS-2). }\end{array}$ & $\begin{array}{l}\text { Significant improvement in } \\
\text { social interaction. }\end{array}$ \\
\hline
\end{tabular}




\section{Continued}

\begin{tabular}{|c|c|c|c|c|}
\hline $\begin{array}{l}\text { Najafabadi et al. } \\
\qquad(2018)\end{array}$ & $\begin{array}{l}\text { Sports, Play and Active } \\
\text { Recreation for Kids (SPARK); } \\
36 \text { sessions; } \\
3 \text { sessions per Week; } \\
40 \text { min per session }\end{array}$ & $\begin{array}{l}28 \text { children with ASD; } \\
5 \text { - } 12 \text { years. }\end{array}$ & $\begin{array}{l}\text { Bruininkse Oseretsky } \\
\text { Test of Motor Proficiency } \\
\text { (BOTMP); Autism treatment } \\
\text { evaluation checklist (ATEC); } \\
\text { Gilliam Autism Rating } \\
\text { Scale-second edition (GARS-2). }\end{array}$ & $\begin{array}{l}\text { Improved balance (static and } \\
\text { dynamic), bilateral } \\
\text { coordination and social } \\
\text { interaction. }\end{array}$ \\
\hline $\begin{array}{l}\text { Ringenbach et al. } \\
\qquad(2015)\end{array}$ & Assisted Cycling Therapy; & 10 adolescents with ASD. & & $\begin{array}{l}\text { Improvements in cognitive } \\
\text { planning. }\end{array}$ \\
\hline
\end{tabular}

(BOTMP), Gross Motor Development Test (TGMD-2). Eurofit, a Bertec strength plate (strain gage type, $40-60$ ) and the Stork test were also used to evaluate the static balance.

In order to evaluate the social dimension, we used Gilliam Autism Rating Scale-second edition (GARS-2), Vineland Adaptive Behavior Scale (VABS, Sparrow et al., 1984), Social Skills Improvement System (SSIS, Gresham and N. Elliott), Pediatric Quality of Life 4.0 Generic Core Scales (PedsQL) and Child Health Questionnaire (CHQ).

\section{Conclusion}

The studies presented are quite diverse, with intervention programs whose activities, in some cases, are uncommon. However, all had as objective to prove the benefits of physical activity in the different domains, namely at the motor and social level of children with ASD.

The type of intervention performed varies between Kata techniques and trampoline training, dance, assisted cycling therapy, equine activities, balance and "core" training, exercise-gaming, different basic skills and exercises using Wii console.

When analyzing the results obtained in the different studies, the improvements found in the study population after several weeks of intervention are notorious.

With respect to the sample used in the various studies, it is possible to verify that, in general, the sample consisted of a minimum of 7 and a maximum of 50 children/adolescents with ASD.

In analyzing Table 1, we verified the existence of different proposals of physical activity, such as training of trampolines (Lourenço, Esteves, Corredeira, \& Seabra, 2015a, 2015b) or dance (Krüger, Garcias, Hax, \& Marques, 2018). To improve motor skills, it may improve the motor skills of children with ASD, in a program whose aim was to work the fundamental motor skills (Bremer, Balogh, \& Lloyd, 2014). Also, Dickinson \& Place (2014) verified the existence of significant improvements in all parameters evaluated after an exercise program using the Wii.

In a dance program (Arzoglou, Tsimaras, Kotsikas, Fotiadou, Sidiropoulou, Proios, \& Bassa, 2013) significant improvements in neuro-muscular coordination were recorded. 
Currently, different motor intervention programs are used to develop socialization. Equine therapy activities contributed to the improvement of social function (Borgi, Loliva, Cerino, Chiarotti, Venerosi, Bramini, \& Cirulli, 2016) and improvements in physical, emotional and social functioning and behavior (Lanning, Baier, Ivey-Hatz, Krenek, \& Tubbs, 2014).

Ringenbach, Lichtsinn \& Holzapfel (2015) have proven that an Assisted Cycling Therapy program has contributed to improving in cognitive planning.

On the other hand, in only 36 sessions of SPARK improved balance (static and dynamic), bilateral coordination and social interaction (Najafabadi, Sheikh, Hemayattalab, Memari, Aderyani, \& Hafizi, 2018).

Likewise, the neuromuscular coordination (Arzoglou et al., 2013) and the static and dynamic balance (Golsefidi, Younesi, \& Golsefidi, 2013) showed significant improvements, following physical activity charts, respectively, of training of traditional Greek dance and "core" stabilization training.

According to the literature we consulted, we verified that motor intervention programs in children with ASD seem to be a very pertinent aspect, providing benefits in the different domains, being significant the influence of exercise in this population, both in the improvement of the their physical condition, or in the improvement of cognitive and sensorial capacities.

Since motor deficits are a characteristic of the PEA and the treatment of this pathology should consider interventions to improve these deficits, including motor performance along with motor coordination (gait, balance, arm functions and movement planning) (Fournier et al., 2010). Thus, the use of physical exercise as an instrument for the development of children with autism has been increasingly used, requiring theoretical research that supports this use, giving it greater scientific robustness.

After the research and construction of this article, we concluded that regardless of the type of physical activity, number of sessions or duration of the training program, the results were very positive.

\section{Conflicts of Interest}

The authors declare no conflicts of interest regarding the publication of this paper.

\section{References}

Arzoglou, D., Tsimaras, V., Kotsikas, G., Fotiadou, E., Sidiropoulou, M., Proios, M., \& Bassa, E. (2013). The Effect of $\alpha$ Traditional Dance Training Program on Neuromuscular Coordination of Individuals with Autism. Journal of Physical Education and Sport, 13, 563-569. https://doi.org/10.7752/jpes.2013.04088

Baranek, G. T. (2002). Efficacy of Sensory and Motor Interventions for Children with Autism. Journal of Autism and Developmental Disorders, 32, 397-422. https://doi.org/10.1023/A:1020541906063

Borgi, M., Loliva, D., Cerino, S., Chiarotti, F., Venerosi, A., Bramini, M., \& Cirulli, F. (2016). Effectiveness of a Standardized Equine-Assisted Therapy Program for Children 
with Autism Spectrum Disorder. Journal of Autism and Developmental Disorders, 46, 1-9. https://doi.org/10.1007/s10803-015-2530-6

Bremer, E., Balogh, R., \& Lloyd, M. (2014). Effectiveness of a Fundamental Motor Skill Intervention for 4-Year-Old Children with Autism Spectrum Disorder: A Pilot Study. Autism, 19, 980-991. https://doi.org/10.1177/1362361314557548

Bremer, E., Crozier, M., \& Lloyd, M. (2016). A Systematic Review of the Behavioural Outcomes Following Exercise Interventions for Children and Youth with Autism Spectrum Disorder. Autism, 20, 899-915. https://doi.org/10.1177/1362361315616002

Chanias, A., Reid, G., \& Hoover, M. (1998). Exercise Effects on Health-Related Physical Fitness of Individuals with an Intellectual Disability: A Meta-Analysis. Adapted Physical Activity Quarterly, 15, 119-140. https://doi.org/10.1123/apaq.15.2.119

Cheldavi, H., Shakerian, S., Shetab Boshehri, S. N., \& Zarghami, M. (2014). The Effects of Balance Training Intervention on Postural Control of Children with Autism Spectrum Disorder: Role of Sensory Information. Research in Autism Spectrum Disorders, 8, 8-14. https://doi.org/10.1016/j.rasd.2013.09.016

Dickinson, K., \& Place, M. (2014). A Randomised Control Trial of the Impact of a Computer-Based Activity Programme upon the Fitness of Children with Autism. Autism Research and Treatment, 2014, Article ID: 419653. https://doi.org/10.1155/2014/419653

Dillon, S. R., Adams, D., Goudy, L., Bittner, M., \& McNamara, S. (2017). Evaluating Exercise as Evidence-Based Practice for Individuals with Autism Spectrum Disorder. Frontiers in Public Health, 4, 290. https://doi.org/10.3389/fpubh.2016.00290

Fournier, K. A., Hass, C. J., Naik, S. K., Lodha, N., \& Cauraugh, J. H. (2010). Motor Coordination in Autism Spectrum Disorders: A Synthesis and Meta-Analysis. Journal of Autism and Developmental Disorders, 40, 1227-1240.

https://doi.org/10.1007/s10803-010-0981-3

Golsefidi, N. R., Younesi, A., \& Golsefidi, A. S. (2013). Effects of 8-Week Core Stabilization Exercises on the Balance of Students with High-Functioning Autism. International Journal of Sport Studies, 3, 1369-1374.

Hilton, C. L., Cumpata, K., Klohr, C., Gaetke, S., Artner, A., Johnson, H., \& Dobbs, S. (2014). Effects of Exergaming on Executive Function and Motor Skills in Children with Autism Spectrum Disorder: A Pilot Study. American Journal of Occupational Therapy, 68, 57-65. https://doi.org/10.5014/ajot.2014.008664

Ketcheson, L., Hauck, J., \& Ulrich, D. (2017). The Effects of an Early Motor Skill Intervention on Motor Skills, Levels of Physical Activity, and Socialization in Young Children with Autism Spectrum Disorder: A Pilot Study. Autism, 21, 481-492. https://doi.org/10.1177/1362361316650611

Kiphard, E. J., \& Schilling, V. F. (1974). Körper-koordinations-test für kinder KTK: manual Von Fridhelm Schilling. Weinhein: Beltz Test.

Koenig, K., White, S. W., Pachler, M., Lau, M., Lewis, M., Klein, A. et al. (2010). Promoting Social Skill Development in Children with Pervasive Developmental Disorders: A Feasibility and Efficacy Study. Journal of Autism and Developmental Disorders, 40, 1209-1218. https://doi.org/10.1007/s10803-010-0979-x

Krüger, G. R., Garcias, L. M., Hax, G. P., \& Marques, A. C. (2018). O efeito de um programa de atividades rítmicas na interação social e na coordenação motora em crianças com transtorno do espectro autista. Revista Brasileira de Atividade Física \& Saúde, 23, 1-5. https://doi.org/10.12820/Rbafs.23e0046

Lang, R., Liu, T., \& Ledbetter-Cho, K. (2018). Exercise in Autism. In Encyclopedia of Autism Spectrum Disorders (pp. 1-6). New York: Springer. 
https://doi.org/10.1007/978-1-4614-6435-8_102189-1

Lanning, B. A., Baier, M. E. M., Ivey-Hatz, J., Krenek, N., \& Tubbs, J. D. (2014). Effects of Equine Assisted Activities on Autism Spectrum Disorder. Journal of Autism and Developmental Disorders, 44, 1897-1907. https://doi.org/10.1007/s10803-014-2062-5

Loh, A., Soman, T., Brian, J., Bryson, S. E., Roberts, W., Szatmari, P., \& Zwaigenbaum, L. (2007). Stereotyped Motor Behaviors Associated with Autism in High-Risk Infants: A Pilot Videotape Analysis of a Sibling Sample. Journal of Autism and Developmental Disorders, 37, 25-36. https://doi.org/10.1007/s10803-006-0333-5

Lourenço, C., Esteves, D., Corredeira, R., \& Seabra, A. (2015a). The Effect of a Trampoline-Based Training Program on the Muscle Strength of the Inferior Limbs and Motor Proficiency in Children with Autism Spectrum Disorders. Journal of Physical Education and Sport, 15, 592-597.

Lourenço, C., Esteves, D., Corredeira, R., \& Seabra, A. (2015b). Children with Autism Spectrum Disorder and Trampoline Training. Wulfenia Journal, 22, 342-351.

Movahedi, A., Bahrami, F., Marandi, S. M., \& Abedi, A. (2013). Improvement in Social Dysfunction of Children with Autism Spectrum Disorder Following Long Term Kata Techniques Training. Research in Autism Spectrum Disorders, 7, 1054-1061. https://doi.org/10.1016/j.rasd.2013.04.012

Najafabadi, M. G., Sheikh, M., Hemayattalab, R., Memari, A. H., Aderyani, M. R., \& Hafizi, S. (2018). The Effect of SPARK on Social and Motor Skills of Children with Autism. Pediatrics and Neonatology, 59, 481-487. https://doi.org/10.1016/j.pedneo.2017.12.005

Neto, F. R. (2007). Manual de avaliação motora. [recurso eletrônico]. Dados eletrônicos. Porto Alegre: Artmed.

Ozonoff, S., Young, G., Goldring, S., Hess, L., Herrera, A., \& Steele, J. (2008). Gross Motor Development, Movement Abnormalities and Early Identification of Autism. Journal of Autism and Developmental Disorders, 38, 644-656. https://doi.org/10.1007/s10803-007-0430-0

Pan, C.-Y., Tsai, C.-L., \& Chu, C.-H. (2009). Fundamental Movement Skills in Children Diagnosed with Autism Spectrum Disorders and Attention Deficit Hyperactivity Disorder. Journal of Autism and Developmental Disorders, 39, 1694-1705. https://doi.org/10.1007/s10803-009-0813-5

Ringenbach, S., Lichtsinn, K. C., \& Holzapfel, S. D. (2015). Assisted Cycling Therapy (ACT) Improves Inhibition in Adolescents with Autism Spectrum Disorder. Journal of Intellectual and Developmental Disability, 40, 376-387. https://doi.org/10.3109/13668250.2015.1080352

Sam, K. L., Chow, B. C., \& Tong, K. K. (2015). Effectiveness of Exercise-Based Interventions for Children with Autism: A Systematic Review and Meta-Analysis. International Journal of Learning and Teaching, 1, 98-103. https://doi.org/10.18178/ijlt.1.2.98-103

Shallice, T. (1982). Specific Impairments of Planning. Philosophical Transactions of the Royal Society of London. Biology, 298, 199-209. https://doi.org/10.1098/rstb.1982.0082

Sowa, M., \& Meulenbroek, R. (2012). Effects of Physical Exercise on Autism Spectrum Disorders: A Meta-Analysis. Research in Autism Spectrum Disorders, 6, 46-57. https://doi.org/10.1016/j.rasd.2011.09.001

Sparrow, S. S, Balla, D. A, \& Cicchetti, D. V. (1984). Vineland Adaptive Behavior Scales. Circle Pines, MN: American Guidance Service.

Wind, W. M., Schwend, R. M., \& Larson, J. (2004). Sports for the Physically Challenged Child. Journal of the American Academy of Orthopaedic Surgeons, 12, 126-137. https://doi.org/10.5435/00124635-200403000-00008 